\title{
Bio Diesel as an Alternative Green Fuel to Internal Combustion Diesel Engine
}

\author{
M. Srinivasnaik, Dr.T.V.V. Sudhakar and Dr.B. Balu Naik
}

\begin{abstract}
The bio-fuels such as alcohols and biodiesel have been proposed as alternatives to Internal Combustion Engine diesel fuel because of their bio degradability and non toxicity. These fuels have received wide attention because They significantly reduce exhaust emissions and the overall life cycle emissions of carbon dioxide $\left(\mathrm{CO}_{2}\right)$ when they burnt as fuel. In 1973 OPEC (Organization of Petrol Exporting Countries, founded in 1960) put an embargo on oil production and started an oil pricing control strategy. Oil prices shot up four folds causing severe energy crisis the world over. This resulted in spiraling price rise of various commercial energy sources leading to global inflation. The world took this shock very seriously and for the first time a need for developing of alternative sources of energy was felt. Alternative energy sources were given serious consideration and huge funds were allocated for the development of these resources. Thus, 1973 is considered as the year of the first 'oil shock'. Two more 'oil shock's jolted the world one in 1979 and the other one in 1990, which further focused the attention on alternative energy sources. Vegetable oils, edible or non- edible can be used as such or blended with diesel as diesel engine fuel. Some plants (e.g. Euphorbia lathyris) can be used to produce hydrocarbons, which have molecular weights very close to petroleum. It also produces sugar as a byproduct. However, the technology of such things is at the research stage, and its economic viability has not been assessed yet. Increased biodiesel (Jatropha) oil production delivers economic benefits to India on the macroeconomic or national level as it reduces the nation's fossil fuel import bill for diesel production; minimizing the expenditure of India's foreign-currency reserves for fuel allowing India to increase its growing foreign currency reserves (which can be better spent on capital expenditures for industrial inputs and production).This paper critically examines the Entrepreneurship opportunities for bio-diesel production in India.
\end{abstract}

Keywords--- Biodiesel, Production of Bio Diesel, Blends, Esterification Process and Pyrolasis

\section{INTRODUCTION}

$\mathrm{I}^{\mathrm{N}}$ $\mathrm{N}$ India large plots of waste land have been selected for Jatropha cultivation for the productivity of biodiesel which will provide much needed employment to the rural poor of India. Businesses are also seeing the planting of Jatropha as a

M. Srinivasnaik, Research Scholar, Department of Mechanical Engineering, JNTU, Hyderabad, India. E-mail: srinivasmukuloth@gmail.com

Dr.T.V.V. Sudhakar, Professor, Department, of Mechanical Engineering, CIET, Raipur, India. E-mail:tvvsudhakar@gmail.com

Dr.B. Balu Naik, Professor, Department, of Mechanical Engineering, JNTU, Hyderabad, India. E-mail:banothbn@rediffmail.com DOI: 10.9756/BIJIEMS.8062 good business opportunity. The Government of India has identified 400,000 square kilometers (98 million acres) of land where Jatropha can be grown, hoping it will replace $20 \%$ of India's diesel consumption. Life-cycle analysis studies have shown favorable energy balance for the production of jatropha-based biodiesel in India and also a potential GHG emission saving of 33-42\% compared to fossil-based diesel Petroleum products, the actual base of the world energy matrix, are causing serious problems to the environment. The alternative fuels can be used as a substitutes to conventional petroleum diesel fuels. The search for alternative fuels is in demand due to concerns about depletion of fossil fuel reserves and also growing worldwide stringent environmental pollution. The fuel derived from renewable biological resources for use in diesel engines is known as bio-diesel [1]. It is the mono alkyl esters of long chain fatty acids derived from renewable lipid sources [2]. Biodiesel is typically produced through the reaction of a vegetable oil or animal fat with methanol in the presence of a catalyst to yield glycerin and methyl esters $[3,4]$. The process of production of biodiesels is called transesterification $[5,6,7,8]$. There are several of species from which biodiesels can be made available. Biodiesel can be harvested and sourced from nonedible oils like Jatropha, Pongamia, Neem (Azadirachta indica), Mahua, castor, linseed, Kusum (Schlechera trijuga), etc and edible oils like Coconut, Palm, Sunflower ,Mustered, Soybean etc $[9,10]$. Out of these plants, Soybean and Pongamia Pinnata, can be grown in arid and wastelands. Biodiesel has some important advantages when compared to diesel fuel. Biodiesel contains almost no sulphur; is biodegradable, nontoxic and a natural lubricant. Biodiesel has a high flashpoint, about $130^{\circ} \mathrm{C}\left(266^{\circ} \mathrm{F}\right)$, so it does not explode spontaneously or ignite under normal circumstance. This feature makes biodiesel much safer to transport and store. Although biodiesel contains $10 \%$ less energy per gallon than conventional diesel fuel, it exhibits almost the same performance compared to diesel fuel, because, beyond reduces engine friction between engine parts, biodiesel useable energy is partially offset by approximately $7 \%$ increase in the combustion efficiency. Biodiesel has others advantages, compared to conventional diesel fuel, such as: ready availability, renewability, biodegradability, higher centane number, flash point, cloud point and cold filter plugging point. Since biodiesel comes from a renewable energy source, its production and use as a replacement for fossil fuel provides three main benefits: reduces economic dependence on petroleum oil; decreases gas emissions that cause the greenhouse effect; and diminishes the proliferation of deceases caused by the pollution of the environment. The use of biodiesel in diesel engines require no hardware modification because vegetable oils have cetane numbers close to that of 
diesel fuel. High viscosity of the vegetable oil leads to poor fuel atomization, which in turn may lead to poor combustion, ring sticking, injector cocking, injector deposits, injector pump failure and lubricating oil dilution by crank-case polymerization [11, 12].

\section{LITERATURE SURVEY}

The oils that have been extensively studied in the past include Sunflower, Soya bean, Peanut, Rapeseed, Rice bran, Karanji etc., $[13,14]$. One of the disadvantages of using these oils in diesel engines is nozzle deposits, which drastically affects the engine performance and emissions. The refining processes of vegetable oil gives better performance compared to crude vegetable oil [15, 16, 17, 18]. Goering et al [19] studied the characteristic properties of eleven vegetable oils to determine which oils would be best suited for use as an alternative fuel source. Of the eleven oils tested, corn, rapeseed, sesame, cottonseed, and soyabean oils had the most favorable fuel properties. There is an improvement in the engine performance when these modified vegetable oils are used instead of base vegetable oils [20, 21, 23, 24]. This improvement in performance is attributed to good atomization of these modified fuels in the injector nozzle and a significant reduction in the viscosity. The performance of the non-edible oils like Rice bran oil [27] and cotton seed oil [26] was found satisfactory. The idea of using vegetable oils as fuel for diesel engines is not a new one. Rudolf Diesel the inventor of the diesel engine reportedly used peanut(groundnut) oil in his engine for demonstration purpose in 1900[28].However, despite the technical feasibility, vegetable oil as fuel could not get acceptance, as it was more expensive compared to petroleum fuels. The vegetable oils are not proper to replacements frankly for Diesel fuel, due to their longer molecule chain, higher viscosity and higher flash point[29].The comparison of various properties and combustion characteristics of available vegetable oils is given in the table1[30]. Later the various factors as stated earlier, created renewed interest of researchers in vegetable oil as substitute fuel for diesel engines. The density and viscosities of the blends increased with the increase of biodiesel concentration in the fuel blend. It also reduces the filter clogging and ensures smooth flow of oil. Some of the researchers [22,25] conducted the experiments on diesel engine using non-edible vegetable oils used as alternate fuels and found maximum Brake thermal efficiency, BSFC and emissions like $\mathrm{CO}, \mathrm{HC}$ also increased without any engine modification. The 8 uses of biodiesel [31] in conventional diesel engines result in substantial reduction in the emission of unburned hydrocarbons, carbon monoxide and particulate. Neat oil is converted into Methyl ester of oil (biodiesel) using trans-esterification process. Methyl and ethyl ester of Karanja oil[32] can also be used as fuel in compression ignition engine without any engine modification. Higher viscosity is responsible for various undesirable combustion properties of Neat vegetable oils. Four well known techniques are proposed to reduce the viscosity levels of vegetable oil namely dilution, Pyrolysis, Micro emulsion and Trans esterification [33].
Agarwal [34] conducted an experiment on a diesel engine and observed significant improvement in engine performance and emission characteristics of the biodiesel fuelled engine compared to diesel fuelled engine. Thermal efficiency of the engine improved, brake specific fuel consumption reduced and a considerable reduction in the exhaust smoke opacity was observed. Goering et al [35] studied the characteristic properties of eleven vegetable oils to determine which oils would be best suited for use as an alternative fuel source. Of the eleven oils tested, corn, rapeseed, sesame, cottonseed, and soyabean oils had the most favorable fuel properties. Altin et al. [36] evaluated the performance and exhaust emissions of a diesel engine using $100 \%$ refined vegetable oil and their biodiesel. The authors concluded that biodiesel have better performance. Pramanik et al. [37] evaluated the engine performance using the prepared Jatropha blends as fuel. Author reported that significant improvement in engine performance was observed compared to vegetable oil alone. The specific fuel consumption and the exhaust gas temperature were reduced due to decrease in viscosity of the vegetable oil and emission characteristics closer to the diesel fuel. Barabas et al. [38] studied the properties, performance and emissions of the diesel-biodiesel-ethanol blends and comparing them with those of diesel fuel. They reported that, performances decrease, especially at low engine loads. CO emissions decrease significantly due to an increase of $\mathrm{CO} 2$ emissions, as a result of a prolonged oxidation process.

Table 1: The Comparison of Physical Properties and Combustion Characteristics of Available Vegetable Oils

\begin{tabular}{|l|l|l|l|l|l|l|}
\hline property & Linseed & Castor & $\begin{array}{l}\text { Palm } \\
\text { stearin }\end{array}$ & Mahua & Neem & Diesel \\
\hline $\begin{array}{l}\text { Density } \\
(\text { Kg/m } \\
40^{\circ} \mathrm{C}\end{array}$ & 929 & 956 & 918 & 917 & 919 & 830 \\
\hline $\begin{array}{l}\text { Viscosity } \\
\text { (cst) }\end{array}$ & 22.2 & 52 & 39.6 & 36 & 34 & 5.0 \\
\hline $\begin{array}{l}\text { Flash point } \\
\left({ }^{0} \mathrm{C}\right)\end{array}$ & 241 & 320 & 220 & 273 & 300 & 57 \\
\hline $\begin{array}{l}\text { Fire point } \\
\left({ }^{0} \mathrm{C}\right)\end{array}$ & 260 & 345 & 280 & 301 & 325 & 65 \\
\hline $\begin{array}{l}\text { Calorific } \\
\text { values } \\
(\mathrm{KJ} / \mathrm{Kg})\end{array}$ & 39307 & 36000 & 37500 & 39600 & 35200 & 42000 \\
\hline $\begin{array}{l}\text { Cetane } \\
\text { number }\end{array}$ & 34.6 & 42.3 & 42 & 45 & 38 & 50 \\
\hline
\end{tabular}

From the Table 1: it could be seen that Vegetable oil has slightly lower calorific value than diesel oil. This can be attributed to presence of oxygen in the molecule of vegetable oils. Vegetable oil has cetane number about 35 to 40 depending on composition whereas diesel fuels have a cetane number around 45 to 50 . Certain functional groups and the poor volatility is responsible for their comparatively low cetane number. Vegetable oil and diesel differs greatly in other properties. Their kinematic viscosity is several times greater than for diesel oil. The kinematic viscosity of vegetable oil at $40 \mathrm{C}$ is in the range of 35 to $45 \mathrm{cSt}$ whereas for diesel oil is $5 \mathrm{cSt}$. Other disadvantages of vegetable oil are large carbon residue, the high viscosity of vegetable oils lead to pumping and atomization problems in the normal diesel fuel injection system, which creates filter plugging and cold starting. High carbon residue causes heavy smoke emission and carbon deposition on the injection nozzle tips and in the 
combustion chamber. There are also problems of incompatibility with engine lubricants. The poor volatility makes vegetable oil difficult to vaporize and ignite. This leads to thermal cracking resulting in the heavy smoke emission and carbon deposits in the combustion chamber. This tendency is partly due to higher fuel viscosity. Vegetable oil dilutes the lubricant oil and forms sludges on all parts of engine, which come in Contact with lubricating oil.

The Remedial methods are Fuel modification through pyrolysis, micro- emulsification, dilution and transesterification. The starting problems can be overcome by using glow plugs and fuel heaters. Filter plugging can be minimized if crude degummed oils have been passed through a four micrometer filter.

The Procedure in the Manufacturing of Biodiesel is as follows

Take $80 \%$ Diesel and 20\% oil. The oil can be sunflower, mustard, Jatropha, cottonseed pongamia and soyabeen. Mix thoroughly both of them in a standard beaker which is a funnel shaped vessel having a flow control valve at the bottom. Allow the mixture in the vessel for 2 to 3 hours. At the end of the time period open the controlling valve provided in the bottom end of the vessel. Collect the bio diesel in the container. This method of preparing the bio diesel is valid only for 80-20 mixture.

\section{The Second Method of Preparing the Bio Diesel is known as Trans-Esterification Process}

For one litter of any oil such as sun flower, cotton seed oil, pongamia, and jatropha etc add $100 \mathrm{ml}$ of methanol or ethanol. To this mixture add 6 to 7 grams of $\mathrm{NaoH}$. Heat the entire volume to $60^{\circ} \mathrm{c}$. At the end of heating, pour the heated contents in a funnel shaped vessel having a controlling valve at the bottom. Allow 2 hours time for the contents to settle down. At the end of 2 hours time glycol layer forms bellow the oil layer in the funnel shaped beaker. Empty the glycol layer at the end of two hours and through it out or use it for some other purposes. Collect the oil from funnel shaped vessel in a beaker. Measure the oil that has been collected. Add 3 times of water to the collected oil. Allow the whole suspension for 2 hours. Transfer the suspension in funnel shaped vessel and allow it to settle down for 2 hours. At the end of 2 hours we observe three layers. The first layer is known as the fat layer which forms at the top of the oil layer. The oil layer forms in the middle of the two layers. The third layer which forms at the bottom of the two layers is known as water layer. Take three beakers and empty the contents in the beakers such that the fat layer will be in beaker one, oil will be in beaker two and water will be in beaker three. Take oil beaker and heat up to $60^{\circ} \mathrm{C}$ by allowing dissolved water to evaporate from the oil. The oil so obtain is bio diesel that can be directly used as a fuel in Internal Combustion Engines. The fuel modification methods such as pyrolysis, micro- emulsification, dilution and trans-esterification have been detailed by balakrishna et,al;[39].In Table 2 the physical and combustion properties of few vegetable oils are detailed[40].
Table 2: The Physical and Chemical Properties of Few Vegetable Oils

\begin{tabular}{|l|l|l|l|l|}
\hline Properties & $\begin{array}{l}\text { Rapeseed } \\
\text { oil }\end{array}$ & Soybean oil & $\begin{array}{l}\text { Sunflower } \\
\text { oil }\end{array}$ & $\begin{array}{l}\text { Corn } \\
\text { oil }\end{array}$ \\
\hline General formula & $\mathrm{CH}_{1.80} \mathrm{O}_{0.10}$ & $\mathrm{CH}_{1.730} \mathrm{O}_{0.10}$ & ----- & ----- \\
\hline $\begin{array}{l}\text { Carbon content }(\% \\
\text { mass })\end{array}$ & 77.9 & 78.4 & ------ & ----- \\
\hline $\begin{array}{l}\text { Hydrogen content } \\
\text { (\% mass) }\end{array}$ & 11.7 & 11.3 & ------ & ----- \\
\hline $\begin{array}{l}\text { Oxygen content }(\% \\
\text { mass })\end{array}$ & 10.4 & 10.3 & ------ & ----- \\
\hline $\begin{array}{l}\text { Density at } 20^{\circ} \mathrm{C} \\
\text { (kg/m3) }\end{array}$ & 916 & 916 & ------ & ----- \\
\hline $\begin{array}{l}\text { Kinematic viscosity } \\
\text { at 38 }{ }^{\circ} \mathrm{C}(\mathrm{mm} 2 / \mathrm{s})\end{array}$ & 37.0 & $28.5-32.6$ & 37.1 & 34.9 \\
\hline Melting range $\left({ }^{\circ} \mathrm{C}\right)$ & 0 to -2 & -12 to -29 & -18 & - \\
\hline $\begin{array}{l}\text { Heating value } \\
\text { (MJ/kg) }\end{array}$ & 37.440 & 36.825 & ------- & 39.500 \\
\hline Cetane number & $32-36$ & $36-39$ & 37 & 37.6 \\
\hline Flash point $\left({ }^{\circ} \mathrm{C}\right)$ & 246 & 254 & 274 & 277 \\
\hline Cloud point $\left({ }^{\circ} \mathrm{C}\right)$ & -3.9 & -3.9 & 7.2 & -1.1 \\
\hline Pour point $\left({ }^{\circ} \mathrm{C}\right)$ & -31.7 & -12.2 & -15.0 & -40.0 \\
\hline
\end{tabular}

\section{CONCLUSION}

1. India is importing crude petroleum \& petroleum products from Gulf countries. Indian scientists searched for an alternate to diesel fuel to preserve global environment and to withstand economical crisis. So, vegetable oils from plants both edible, crude non-edible and Methyl esters (Bio-diesels) are used as alternate source for Diesel oil. Bio-diesel was found as the best alternate fuel, technically and environmentally acceptable, economically competitive and easily available.

2. Biodiesel can be used as an alternative fuel in the Diesel engine without any Engine modifications.

3. Fuel modification through pyrolysis, microemulsification, dilution and trans-esterification has been sited to overcome the deficiency of the vegetable oil as substitute to diesel engine oil.

4. Setting up a plant on bio-diesel production May leads to substantial savings on Indian Currency by minimizing Imports on Petroleum based diesel crude from abroad.

5. Many countries around the world are involved in the growing use and production of biofuels, such as biodiesel, as an alternative energy source to fossil fuels and oil. To foster the biofuel industry, governments have implemented legislations and laws as incentives to reduce oil dependency and to increase the use of renewable energies. Many countries have their own independent policies regarding the taxation and rebate of biodiesel use, import, and production. 


\section{REFERENCES}

[1] B H Khan Non- conventional energy resources the McGraw-Hill companies, 2006.

[2] Gholamhassan. N., Barat. G., Talal. F. Y. and Hadi. R. , Combustion Analysis of a CI Engine Performance Using Waste Cooking Biodiesel Fuel with an Artificial Neural Network Aid, American Journal of Applied Sciences, Volume 4, Pp 756-764, 2007.

[3] Lee S. W., Herage T. and Young. B., Emissionreduction potential from the combustion of soy methyl ester fuel blended with petroleum distillate fuel. Fuel. Volume 83, Pp 1607-1613, 2004

[4] Anand. R and Kannan. G. R., The performance and emissions of a variable compression ratio diesel engine fuelled with bio-diesel from cotton seed oil. ARPN Journal of Engineering and Applied sciences.Volume 4, Pp 72-86, 2009

[5] Sahoo P.K. and Das L.M., Combustion analysis of Jatropha, Karanja and Polanga based biodiesel as fuel in a diesel engine, Fuel, Volume 88,Pp 994-999, 2009

[6] Sahoo P.K., Das. L.M, Babu. M.K.G and Naik. S.N., Biodiesel development from high acid value polanga seed oil and performance evaluation in a CI engine, Fuel, Volume 86, Pp 448-454. 2007

[7] Balusamy. $\mathrm{T}$ and Marappan. R., Effect of Injection Time and Injection Pressure on CI Engine Fuelled with Methyl Ester of Thevetia Peruviana Seed Oil.International Journal of Green Energy Volume7, Pp 397-409, 2010.

[8] N.R. Banapurmath, P.G. Tewari and R.S. Hosmath., Performance and emission characteristics of a D.I.C.I. Engine operated on Honge, Jatropha and sesame oil methyl esters, Renewable energy.Volume 33, Pp 1982-1988, 2008.

[9] Anjana Srivastava, Ram Prasad., Triglycerides-based diesel fuels. Renewable Sust Energ Volume 4, Pp 111-33, 2000

[10] Yusuf Ali, Hanna MA.,Alternative diesel fuels from vegetable oils. Biores Technol, Volume 50, Pp 153-63, 1994.

[11] Rakopoulos CD, Antonopoulos KA, Rakopoulos DC, Hountalas DT and Giakoumis EG., Comparative performance and emissions study of a direct injection diesel engine using blends of diesel fuel with vegetable oils or bio-diesels of various origins. Energy Conversion Management, Volume 47, Pp 3272-3287, 2006.

[12] Engelman HW, Guenther DA and Silvis TW. 1942. Vegetable oil as a diesel fuel. Diesel and Gas Engine Power Division of ASME paper no. 78-DGP-19. New York: ASME; 1978.

[13] Niehaus, R.A., Georing, C.E., et al., "Cracked Soybean Oil as a Fuel for Diesel Engine”, ASAE Paper NO.85-1560, ASAE, St. Joseph, MI, 1985.

[14] M.L. Schlick, M.A. Hanna and J.L. Schnstock., "Soybean and Sunflower Oil Performance in a Diesel Engine”, Trans. ASAE Volume 31 Issue 5, Pp 1345-1349, 1988.

[15] Sapvan S.M., Nasjuki H.H., Azlan, A., "Use of Palm Oil as Diesel Fuel Substitute", Proceedings of the Institution of Mechanical Engineers, Part-A, Journal of Power and Energy, Volume 210, Pp 47-53, 1996

[16] Rosca Radu and Zugravel Mircea, "The Use of Sunflower Oil in Diesel Engines”, SAE Paper No.972979, 1997.

[17] Cigizoglu, K. Baris, Ozaklam Turgon, Karaosmanuglu. "Use of Sunflower Oil as an Alternative Fuel for Diesel Engines", Energy Sources,Volume 19,Pp 559-566. 6, July,1997

[18] Machacon HTC, Seiichi Shiga, Takao Karasawa, Hisao Nakamura, "Performance and Emission Characteristics of a Diesel Engne Fueled with Coconut Oil - Diesel Fuel Blend”, Journal Biomass Bioenergy, 2001.

[19] C.E. Goering, A.W. Schwab et al., "Fuel Properties of Eleven Vegetable Oils”, Trans. ASAE, Volume 25 4, Pp 1472-1477, 1982.

[20] Harrington, K.J., "Chemical and Physical Properties of Vegetable Oil Esters and their Effect on Diesel Fuel Performance”, Biomass, Volume 9, Pp 1-17, 1986.

[21] Srinivasa Rao, R and Gopala Krishna, K.V., "Esterified Vegetable Oils as Fuels in Diesel Engines", XI National Conference on I.C. Engines \& Combustion.

[22] O.D. Hebbal, K. Vijaya Kumar Reddy and K. Rajagopal, April. "Performance characteristics of a diesel engine with Deccan Hemp oil", Fuel, 2006.

[23] Srinivas, R.P., and Gopalakrishnan, K.V., "Vegetable Oils and their Methyl esters as Fuels for Diesel Engines", Indian Journal of Technology, Volume 29, Pp 292-297, 1991
[24] Scholl, K.W and S.C. Sorenson., "Combustion of Soybean Oil Methyl Ester in a Direct Injection Diesel Engine”, SAE Paper No.930934, Warrendale, PA., 1993.

[25] S. Choudhury,P. K Bose, Karanja or Jatropha - A better option for an Alternative fuel in CI engine, International Conference On ICEngines(ICONICE), Hyderabad.2007.

[26] Leenus JesuMartin .M, prithviraj.D, Chandrasekaran.S, Tamilporai.P, Effect of Cotton Seed oil and Diesel Blends on the performance and emission of a compression ignition engine. Proceedings of 19 Th National Conference on I.C.engines and combustion, Annamalai University, Pp 101-105, 2005.

[27] Nag raja. A.M, Prabhu kumar.G.P, performance of Diesel, Neat Biodiesel and 20\% Biodiesel - A comparative study. Proceedings of 19 The National Conference on I. C. engines and combustion, Annamalai University, Pp 503-508, 2005.

[28] A.V.Sitarama Raju, P.Ravi Kumar Experimental investigations of ic engine with pongamia diesel Blends IJAET/Volume2 Issue 4, Pp 54-58, 2011.

[29] Ma. F., Hanna. MA., "Biodiesel production: a review". Bioresour Technol Volume 70, Pp 1-15, 1999;

[30] CH Nagaprasad and Dr.K Vjayakumar Readdy Performance and emission characteristics of a diesel engine with castor oil”, Indian Journal of Science and Technology, Volume 2, Issue 10, Pp.25-31. 2009

[31] Avinash Kumar Agarwal, Biofuels (alcohols and biodiesel) applications as fuels for internal combustion engines, Progress in Energy and Combustion Science, Volume 33 Pp 233-271. 2007

[32] B. Baiju, M.K. Naik, L.M. Das, A comparative evaluation of compression ignition engine characteristics using methyl and ethyl esters of Karanja oil ,Renewable Energy, Volume 34 Pp 1616-1621. 2009

[33] Ramdas AS, Jayaraj S, Muraleedhran C, "use of vegetable oils on IC Engines fuels - A Review” Renewable .Energy, Volume 29 Pp 727 742, 2004.

[34] Agarwal, D.; Kumar, L.; Agarwal, A.K., Performance evaluation of a vegetable oil fuelled compression ignition engine. Renewable Energy Volume 33, Pp 1147-1156, 2008.

[35] C.E. Goering, A.W. Schwab et al., Fuel Properties of Eleven Vegetable Oils, Trans. ASAE, Volume 25 Issue 6,Pp 1472-1477, 1982.

[36] Agba, A. M. Ogaboh, Ushie, M. E., F. I., Abam, Michael S. Agba, James Okoro, Developing the Biofuel Industry for Effective Rural Transformation in Nigeria, European Journal of Scientific Research Volume 40 Issue 3, Pp 441-449, 2010.

[37] Pramanik, K., Properties and use of jatropha curcas oil and diesel fuel blends in compression ignition engine, Renewable Energy Volume 28, Pp 239-248, 2008.

[38] Barabas, István., Adrian Todorut and Doru Baldean, Performance and emission characteristics of a CI engine fueled with diesel-biodieselbioethanol blends, Fuel, Volume 89, Pp 3827-3832, 2010.

[39] B.Balakrishna vegetable oil as fuel in CI Engine: problems and possible solutions. IJEST volume 4, Pp, 4687-4690, 2012.

[40] A kowalewicz and M Wojtyniak. Alternative fuels and their application to combustion engines. IMechE. Volume 219 part D: J.Automobile Engineering-2005.

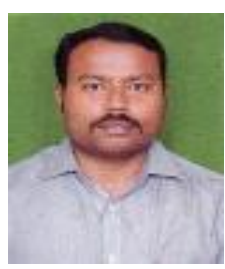

M. Srinivasnaik was born in Karimnagar, Telangana, India. He received his Bachelor degree in Mechanical Engineering from JNTU Hyderabad India in 2005 and successfully completed M.Tech degree with first class and distinction in Mechanical engineering JNTU Hyderabad, Telangana, India in 2007. He is presently working as Associate Professor in the department of Mechanical Engineering Vivekananda Institute of Technology and Science karimnagar. He has registered for pursuing Ph.D at JNTU Hyderabad, under the guidance of Prof.T V V Sudhkar and Prof B. Balunaik. He is specializing for the Ph.D an alternative fuels to Internal Combustion Engine Diesel fuels he has published papers related to his Ph.D in several national and International journals he has attended few conferences an Alternative fuels he attended many faculty

development programs, workshops and seminars within the India.

Contact Details- Mr. M Srinivasnaik. H-No: 8-12 Village: Gatlakunta, Post: Dhanwada, Mandal: Kataram, Dist: Karimnagar. Telangana State Pin: 505503, Country: India. Mobile +91 9494992616.

E-Mail: srinivasmukuloth@gmail.com 